\title{
EKSPLORASI BAKTERIOSIN DARI BAKTERI ASAM LAKTAT ASAL RUSIP BANGKADAN KALIMANTAN
}

\section{Exploration of Bacteriocin from Lactic Acid Bacteria Origin from Bangkanese and Kalimantanese Rusip}

\author{
Arifah Kusmarwati ${ }^{1^{*}}$, Fadila Rachman Arief $^{2}$, dan Sakinah Haryati ${ }^{2}$ \\ ${ }^{1}$ Balai Besar Penelitian dan Pengembangan Pengolahan Produk dan Bioteknologi Kelautan dan Perikanan, \\ JI. K.S. Tubun Petamburan VI, Jakarta Pusat, Indonesia \\ 2 Universtias Sultan Ageng Tirtayasa, Indonesia \\ * Korespondensi Penulis: akusmarwati@gmail.com \\ Diterima: 11 Maret 2014; Disetujui: 3 Juni 2014
}

\begin{abstract}
ABSTRAK
Penelitian ini dilakukan untuk memproduksi dan mengkarakterisasi bakteriosin yang dihasilkan oleh bakteri asam laktat yang diisolasi dari rusip. Rusip merupakan produk ikan fermentasi tradisional Bangka. Penelitian ini menggunakan sampel rusip yang berasal dari Bangka dan Kalimantan. Sampel diisolasi hingga diperoleh isolat murni yang selanjutnya dilakukan skrining untuk memperoleh isolat yang mampu menghasilkan aktivitas antibakteri tertinggi. Isolat terpilih selanjutnya diidentifikasi dan digunakan untuk memproduksi bakteriosin kasar. Bakteriosin kasar diuji sensitifitasnya terhadap enzim proteolitik dan dikarakterisasi melalui pengujian stabilitas terhadap suhu tinggi, $\mathrm{pH}$, surfaktan, serta stabilitasnya selama penyimpanan. Hasil penelitian menunjukkan bahwa isolat RK4 menghasilkan bakteriosin yang bersifat sensitif terhadap enzim proteolitik seperti proteinase-K dan papain. Bakteriosin tersebut stabil terhadap suhu tinggi dan pH 2-8 serta menghasilkan aktivitas antibakteri yang tertinggi terhadap Staphylococcus aureus. Hasil identifikasi memperlihatkan bahwa isolat RK4 termasuk dalam jenis Pediococcus pentosaceus I. Bakteriosin dari Pediococcus pentosaceus I tersebut aktivitasnya distimulasi oleh EDTA, sodium dodecyl sulphate (SDS) dan lauryl sarcosine. Namun sebaliknya, bioaktivitasnya tidak dipengaruhi oleh Triton X-100, Tween 20, Tween 80 dan urea. Bakteriosin kasar RK4 stabil pada penyimpanan suhu $37^{\circ} \mathrm{C}$ selama 4 minggu dan pada suhu dingin selama 2 minggu.
\end{abstract}

KATA KUNCl: bakteriosin, rusip, Pediococcus pentosaceus I, suhu tinggi

\section{ABSTRACT}

Research was conducted to produce and characterize bacteriocin produced by lactic acid bacteria $(L A B)$ isolated from rusip, a traditional Bangkanese fermented fish product. Research used rusip samples from Bangka and Kalimantan. Experiments were started by isolation of lactic acid bacteria from rusip, followed by screening to obtain the best isolate in producing high bacterial inhibition activity. The selected isolate was then identified and used to produce crude bacteriocin. The crude bacteriocin was observed sensitivity to proteolytic enzymes, and characterized, in term of its stability to high temperature, $\mathrm{pH}$, surfactants, and stability during storage. The result showed that RK4 isolate was sensitive to proteolityc enzyme, i.e proteinase-K and papain. The bacteriocin was heat stable, stable at $\mathrm{pH} 2-8$, and produced the highest inhibition activity to Staphylococcus aureus. Identification result showed that RK4 isolate was Pediococcus pentosaceus I. Bacteriocin which was identified as Pediococcus pentosaceus was stimulated by EDTA, sodium dodecyl sulphate (SDS) and lauryl sarcosine. On the contrary, bioactivity of bacteriocin was not affected by Triton X-100, Tween 20, Tween 80 and urea. Meanwhile, crude bacteriocin RK4 was also stable at storage temperature of $37^{\circ} \mathrm{C}$ for 4 weeks and cold temperature for 2 weeks.

KEYWORDS: bacteriocin, rusip, Pediococcus pentosaceus I, high temperature

\section{PENDAHULUAN}

Bakteriosin didefinisikan sebagai senyawa antimikrobia yang disintesis oleh berbagai spesies bakteri termasuk kelompok bakteri asam laktat (BAL) di dalam ribosom. Bakteriosin merupakan senyawa protein yang mempelihatkan aktivitas antibakteri (bakterisida ataupun bakteriostatik) terhadap spesies 
bakteri yang bersifat sensitif. Protein ini seringkali aktif melawan spesies lain yang memiliki hubungan kekerabatan yang dekat dengan mikroorganisme penghasil (Klaenhammer, 1988; Kaiser et al., 1993 dalam Galvez et al., 2007). Beberapa BAL memproduksi bakteriosin dengan spektrum penghambatan luas. Beberapa bakteriosin juga berpotensi sebagai pengawet pangan. Penggunaan bakteriosin pada industri pangan dapat membantu mengurangi penggunaan bahan pengawet kimiawi ataupun perlakuan panas yang intensif. Dalam hal ini penggunaan bakteriosin secara alami akan memberikan nutrisi dan sifat organoleptik yang lebih baik (Galvez et al., 2007). Selain itu bakteriosin yang berasal dari bakteri asam laktat dikatakan sangat menarik disebabkan ia merupakan bahan tambahan pangan yang aman dan tidak toksis untuk pengawet pangan dan mampu mencegah kerusakan pangan oleh bakteri patogen yang berifat Gram Positif (Morisset et al., 2004 dalam Hata et al., 2010). Melalui penelitian yang sangat intensif, nisin terbukti sebagai satu-satunya bakteriosin yang dapat diaplikasikan pada industri pangan dan telah dipasarkan hingga lebih dari 48 negara (De Arauz et al., 2009). Hingga saat ini nisin telah digunakan sebagai pengawet alami pada produk keju dan makanan kaleng di berbagai negara antara lain Argentina, Australia, Brazil, Italia, Belanda, AS dan Inggris. Dosis nisin yang dipergunakan mulai dari $100 \mathrm{Ul} / \mathrm{ml}$ hingga tidak terhingga (Cleveland et al., 2001 dalam De Arauz et al., 2009).

Beberapa bakteriosin diproduksi dari bakteri asam laktat yang berasosiasi dengan produk-produk fermentasi. Beberapa bakteriosin terbaru dari produk fermentasi antara lain : bakteriosin yang diisolasi dari produk daging terfermentasi asal Turki (Con \& GoÈ kalp, 2000), bakteriosin asal Brazilia (De Martinis \& Freitas, 2003), bakteriosin dari produk fermentasi asal Burkina Faso (Omar et al., 2006), bakteriosin yang diisolasi dari produk daging fermentasi tradisional China (Liu et al., 2008), bakteriosin dari sosis kering (Castro et al., 2011), bakteriosin dari produk daging kering fermentasi asal Brasil (Biscola et al., 2013) dan bakteriosin yang diisolasi dari pasta udang asal Thailand (Kaewkloma et al., 2013). Bakteriosin lain juga dihasilkan oleh strain Lactococcus lactis, Pediococcus acidilactici 13, Lactobacillus plantarum A-1, Lactobacillus curvatus MBSa2, Bacillus licheniformis $\mathrm{P} 40$, Lactobacillus plantarum 17.2b, dan Lactobacillus pentosus B96 (Cladera-Olivera et al., 2004; Delgado et al., 2007; Alegria et al., 2010; Altuntas et al., 2010; Hata et al., 2010; Hurtado et al., 2011; Biscola et al., 2013; dan Barbosa et al., 2015).

Pada penelitian ini beberapa strain bakteri asam laktat telah diseleksi dengan maksud untuk memperoleh bakteriosin baru. Sebuah isolat yang mampu menghasilkan bakteriosin (isolat RK4) telah berhasil diisolasi dari rusip. Rusip merupakan salah satu produk fermentasi ikan yang berasal dari Indonesia. Rusip terbuat dari ikan, garam, gula aren, dan beras, namun terkadang tanpa beras, yang selanjutnya difermentasi secara anaerob selama 714 hari (Yuliana, 2007). Rusip terutama diproduksi di Propinsi Kepulauan Bangka Belitung yang secara luas digunakan sebagai campuran sambal dan dikonsumsi bersama nasi dan lalapan. Pada umumnya rusip mengandung bakteri asam laktat seperti Lactobacillus, Streptococcus, Leuconostoc, Pediococcus, dan Enterococcus (Dessi, 1999 dalam Yuliana, 2007; Wijaya, 2007 dalam Sakti (2009)).

Meskipun beberapa penelitian bakteriosin yang dihasilkan oleh produk pangan dari Indonesia pernah dilaporkan, namun eksplorasi bakteriosin yang dihasilkan dari produk fermentasi asli Indonesia masih sangat terbatas. Diantaranya telah dilaporkan adanya bakteriosin yang berasal dari produk daging yang dikemas vakum dan susu yang berasosiasi dengan bakteri asam laktat (Rahayu et al., 1999; Kusmiati \& Malik, 2002; Nugroho \& Rahayu, 2003; Usmiati \& Marwati, 2007; Syahniar, 2009). Penelitian ini bertujuan untuk mengisolasi bakteri asam laktat dari rusip, selanjutnya memproduksi dan mengkarakterisasi bakteriosin dari isolat terpilih yang aktivitasnya stabil pada suhu tinggi.

\section{BAHAN DAN METODE}

\section{Bahan}

Bahan yang digunakan dalam penelitian ini adalah rusip komersial yang diperoleh dari Bangka dan Kalimantan pada tahun 2013. Sampel rusip Bangka berasal dari pasar tradisional kota Pangkalpinang dan pengolah rusip asal kota Mentok, sementara sampel rusip Kalimantan berasal dari pengolah rusip asal kota Mempawah (Kalimantan Barat). Keseluruhan sampel telah diproduksi dalam jangka waktu yang berbedabeda.

Bakteri indikator untuk uji aktivitas bakteriosin yaitu Lactococcus lactis, Salmonella sp., E. colli, Staphylococcus aureus, Listeria monocytogenes, dan Vibrio sp. Media man rogosa and sharpe (MRS) broth dan agar, CM sukrose (Sukrose 1\%, yeast exstract $1 \%$, pepton $0,45 \%, \mathrm{KH}_{2} \mathrm{PO}_{4} 2,84 \%, \mathrm{NaCl} 0,2 \%$, $\left.\mathrm{MgSO}_{4}, 0,02 \%, \mathrm{MnSO}_{4}, 0,005 \%\right)$ dan brain heart infussion (BHI) digunakan sebagai media pertumbuhan Bakteri Asam Laktat (BAL) penghasil bakteriosin, sedangkan media muller hinton agar (MHA) digunakan sebagai media untuk pengujian aktivitas bakteriosin. 


\section{Isolasi Bakteri Asam Laktat (BAL)}

\section{Pertumbuhan awal BAL}

Bakteri asam laktat (BAL) ditumbuhkan dengan cara memasukkan sampel rusip sebanyak $10 \mathrm{gr}$ ke dalam media MRS broth yang selanjutnya diinkubasi pada suhu $35^{\circ} \mathrm{C}$ selama $24-48$ jam.

\section{Isolasi BAL}

Bakteri asam laktat diisolasi langsung dari rusip komersial yang terlebih dahulu ditumbuhkan selama 24-48 jam pada media MRS broth. Metode yang digunakan adalah metode pengenceran yang dilanjutkan dengan plating secara pour plate (Rahayu \& Margino, 1997). Media yang digunakan untuk isolasi BAL adalah MRS agar ditambah $1 \% \mathrm{CaCO}_{3}$ dengan $\mathrm{pH}$ 5. Inkubasi BAL dilakukan pada suhu $35^{\circ} \mathrm{C}$ selama $48 \mathrm{jam}$. Pemilihan isolat yang diduga sebagai BAL didasarkan pada pembentukan zona bening di sekitar koloni. Koloni yang membentuk zona bening selanjutnya digores (distreak) untuk menghasilkan koloni tunggal. Koloni tunggal digores 2-3 kali pada MRS agar hingga diperoleh isolat murni/tunggal. Isolat tunggal yang dihasilkan diidentifikasi secara kualitatif dengan pewarnaan Gram, uji katalase dan uji oksidase. Isolat murni yang bersifat Gram (+), katalase (-) dan oksidase (-) merupakan isolat BAL.

Penyimpanan isolat dilakukan pada pada suhu $4{ }^{\circ} \mathrm{C}$ dalam media $\mathrm{CM}$ sukrose agar miring. Isolat terpilih yang disimpan pada suhu $4{ }^{\circ} \mathrm{C}$ disegarkan kembali (direfresh) dengan media cair CM sukrose ketika akan dipergunakan. Isolat yang tumbuh pada media tersebut selanjutnya diseleksi untuk memperoleh BAL yang menghasilkan senyawa antimikroba.

\section{Skrining BAL Penghasil Senyawa Antimikroba}

Seleksi isolat BAL penghasil senyawa antimikroba dilakukan menggunakan metode spot agar (agar spotted on the lawn method) (Abrams et al., 2011) secara aerobik. Bakteri indikator yang digunakan adalah Staphylococcus aureus ATCC 25923 dari Remel $^{\circledR}$ (UK), Lactococcus lactis, Salmonella sp., E. coli, Listeria monocytogenes dan Vibrio sp. Cawan agar diinokulasi dengan $100 \mu \mathrm{l}$ strain indikator yang terlebih dahulu ditumbuhkan pada media nutrient broth. Aktivitas daya hambat melawan strain indikator diuji menggunakan Muller Hinton Agar (MHA). Muller Hinton Agar yang mengandung strain indikator dispot/ditetesi dengan $10 \mu$ kultur BAL. Dengan cara demikian, maka satu cawan dapat digunakan untuk menguji sekaligus 8-10 isolat BAL. Selanjutnya dilakukan inkubasi semalam pada suhu $37^{\circ} \mathrm{C}$. Isolat yang memiliki kemampuan untuk menghambat bakteri indikator akan memberikan zona jernih di sekitar spot.

\section{Produksi Bakteriosin Kasar}

Produksi bakteriosin kasar mengacu pada Ogunbanwo et al. (2003). Isolat yang telah diseleksi dan menunjukkan aktivitas antimikroba ditumbuhkan pada $\mathrm{CM}$ sukrose pada suhu $35^{\circ} \mathrm{C}$ selama 48 jam. Kultur sel yang terbentuk disentrifugasi (8.000 rpm, suhu $4{ }^{\circ} \mathrm{C}$ selama 15 menit) untuk mendapatkan supernatannya. Supernatan bebas sel diatur pHnya (pH 6) dengan menambahkan $1 \mathrm{M} \mathrm{NaOH}$ (dengan maksud untuk menghilangkan pengaruh asam organik), lalu difiltrasi dengan filter asetat selulose $0,2 \mu \mathrm{m}$. Selanjutnya supernatan bebas sel dipanaskan pada suhu $80^{\circ} \mathrm{C}$ selama 10 menit untuk menghilangkan aktivitas proteolitik dan hidrogen peroksida. Supernatan bebas sel merupakan bakteriosin kasar.

\section{Pengujian Bakteriosin}

Uji aktivitas bakteriosin dilakukan menggunakan metode difusi sumur agar (Ogunbanwo et al., 2003; Udhayashree et al., 2012). Sebanyak $100 \mu$ l bakteri indikator diinokulasi pada media MHA, kemudian dibuat sumuran berdiameter $6 \mathrm{~mm}$ pada agar yang telah memadat. Pada setiap sumuran dimasukkan sebanyak $10 \mu \mathrm{l}$ bakteriosin kasar. Cawan MHA kemudian diinkubasi pada suhu $35^{\circ} \mathrm{C}$ selama 24 jam. Aktivitas bakteriosin ditunjukkan dengan adanya zona bening/halo yang tegas di sekitar sumuran. Aktivitas bakteriosin dinyatakan sebagai Arbitrari Unit (AU) per $\mathrm{ml}$. Satu AU dinyatakan sebagai luas zona hambat per satuan volume sampel bakteriosin yang diuji $\left(\mathrm{mm}^{2} /\right.$ ml) (Usmiati \& Marwati, 2007).

Aktivitas bakteriosin $\left(\mathrm{mm}^{2} / \mathrm{ml}\right)=\mathrm{AU} / \mathrm{ml}$

Keterangan/Note:

$$
=\frac{\mathrm{Lz}-\mathrm{Ls}}{\mathrm{V}}
$$

$\mathrm{Lz}=$ luas zona bening $\left(\mathrm{mm}^{2}\right)$

Ls $=$ luas sumuran $\left(\mathrm{mm}^{2}\right)$

$\mathrm{V}=$ volume sampel $(\mathrm{mL})$

\section{Konfirmasi BAL Penghasil Bakteriosin}

Untuk mengkonfirmasi supernatan BAL yang merupakan bakteriosin dilakukan pengujian aktivitas supernatan tersebut terhadap enzim proteolitik. Supernatan yang kehilangan aktivitas setelah direaksikan dengan enzim proteolitik merupakan bakteriosin sesungguhnya. Enzim proteolitik yang digunakan adalah papain dan proteinase K. Pengujian pengaruh enzim dilakukan sebagai berikut : Sebanyak 
$200 \mu \mathrm{l}$ supernatan bakteriosin dilarutkan dalam $20 \mu \mathrm{l}$ larutan enzim (larutan enzim dibuat dengan cara melarutkan enzim dalam $\mathrm{NaOH}$ atau fosfat buffer $\mathrm{pH}$ 7), lalu diinkubasi pada suhu $37^{\circ} \mathrm{C}$ selama 2 jam. Supernatan BAL yang sensitif terhadap proteinase-K dan papain dipertimbangkan sebagai bakteriosin yang sesungguhnya dan dipilih untuk pengujian berikutnya. Supernatan yang sensitif terhadap enzim proteolitik adalah supernatan tanpa zona bening/halo yang tegas di sekitar sumuran, dan dinyatakan sebagai bakteriosin.

\section{Karakterisasi Bakteriosin}

\section{Pengaruh $\mathrm{pH}$}

Sebanyak $5 \mathrm{ml}$ larutan bakteriosin kasar pada tabung yang berbeda, masing-masing diatur $\mathrm{pH}$ nya pada $\mathrm{pH} 2,4,6,8$, dan 10 menggunakan larutan $\mathrm{NaOH}$ atau $\mathrm{HCl}$. Setelah diinkubasi selama 4 jam pada suhu kamar, selanjutnya aktivitas bakteriosin diuji menggunakan metode difusi sumuran agar. Aktivitas bakteriosin dinyatakan dalam AU/ml (Usmiati \& Marwati, 2007).

\section{Pengaruh surfaktan}

Surfaktan yang digunakan antara lain : triton $\mathrm{x}$ 100, Tween 20, tween 80 , sodium dodecyl sulfat/SDS, EDTA, Urea dan N-Laurylsarcosine. Surfaktan ditambahkan ke dalam masing-masing larutan bakteriosin kasar pada konsentrasi $0,1 \mathrm{ml}$ atau 0,01 g surfaktan per ml bakteriosin. Larutan bakteriosin kasar tanpa surfaktan digunakan sebagai kontrol. Sampel maupun kontrol diinkubasi pada suhu $37^{\circ} \mathrm{C}$ selama 60 menit. Kemudian dilakukan pengujian aktivitas bakteriosin menggunakan metode difusi sumuran agar. Aktivitas bakteriosin dinyatakan dalam $\mathrm{AU} / \mathrm{ml}$

\section{Spektrum aktivitas antibakteri bakteriosin}

Aktivitas antibakteri bakteriosin diuji terhadap beberapa bakteri indikator ( $L$. plantarum, $L$. monocytogenes, Staphylococcus aureus, Salmonella typhimurium dan E. coli) menggunakan metode difusi sumuran agar. MHA diinokulasi dengan $100 \mu \mathrm{L}$. plantarum yang terlebih dahulu ditumbuhkan pada MRS cair, sedangkan L. monocytogenes, Staphylococcus aureus, Salmonella typhimurium dan E. coli ditumbuhkan pada nutrient broth pada suhu $37^{\circ} \mathrm{C}$ selama 24 jam. Sumuran berdiameter $6 \mathrm{~mm}$ pada MHA plate disiapkan dan sebanyak $10 \mu \mathrm{l}$ bakteriosin kasar ditambahkan ke dalam masingmasing sumuran. Cawan MHA kemudian diinkubasi pada suhu $37^{\circ} \mathrm{C}$ selama 24 jam. Aktivitas antimikroba dinyatakan positif jika terbentuk zona bening/halo yang tegas di sekitar sumuran. Aktivitas bakteriosin dinyatakan dalam $\mathrm{AU} / \mathrm{ml}$.

\section{Uji ketahanan terhadap suhu}

Bakteriosin diambil $200 \mu \mathrm{l}$ kemudian di uji ketahanannya terhadap suhu $50^{\circ} \mathrm{C}$ selama 20 menit, $100^{\circ} \mathrm{C}$ selama 20 menit dan $121^{\circ} \mathrm{C}$ selama 15 menit (Osmanagaoglu et al., 1998; Mandal et al., 2008).

\section{Stabilitas bakteriosin selama penyimpanan}

Uji stabilitas dilakukan dengan cara menyimpan bakteriosin pada suhu $-20,4$, dan $37^{\circ} \mathrm{C}$ selama 2 bulan. Selanjutnya dilakukan uji aktivitas dengan metode diffuse agar (Nugroho \& Rahayu, 2003).

\section{Identifikasi}

Isolat terpilih penghasil bakteriosin diidentifikasi menggunakan API $50 \mathrm{CH}$ strip dan API $50 \mathrm{CHL}$ medium (API systems, Biomerieux Sa, Franch).

\section{HASIL DAN PEMBAHASAN}

\section{Isolasi Bakteri Asam Laktat (BAL)}

Skrining/penapisan bakteri asam laktat dilakukan terhadap 18 isolat bakteri yang berhasil diisolasi dari rusip (Tabel 1). Berdasarkan penapisan tersebut dihasilkan 12 isolat bakteri asam laktat. Berdasarkan hasil analisis pengecatan Gram kedua belas bakteri tersebut merupakan bakteri Gram positif, serta menunjukkan hasil uji katalase dan oksidase negatif.

Axelsson (2004) menerangkan bahwa bakteri asam laktat tipikal merupakan bakteri yang bersifat Gram positif, tidak membentuk spora, katalase negatif, tidak memiliki sitokrom, habitat non aerobik namun bersifat aerotolerant, acid tolerant, dan sangat fermentatif, asam laktat merupakan produk akhir yang utama selama fermentasi gula.

\section{Skrining BAL penghasil senyawa antimikroba}

Tahap berikutnya adalah melakukan skrining BAL penghasil senyawa antimikroba terhadap 12 isolat BAL. Dari 12 isolat BAL yang diskrining terdapat 4 isolat yang memiliki aktivitas antimikroba, yaitu RK1, RK2, RK4, dan RAI (Tabel 2). Seleksi BAL yang mampu menghasilkan senyawa antimikroba dilakukan dengan metode spot agar (agar spotted on the lawn method) pada media Muller Hinton Agar (MHA). Pada seleksi tersebut digunakan bakteri uji Vibrio sp., Staphylococcus aureus, Listeria monocytogenes, E. coli, Salmonella sp., dan Lactococcus lactis. Hasil 
Tabel 1. Data isolat bakteri asam laktat (BAL) dari rusip

Table 1. Data of lactic acid bacteria isolate ( $L A B)$ from rusip

\begin{tabular}{|c|c|c|c|c|c|}
\hline No. & $\begin{array}{c}\text { Asal Isolat/ } \\
\text { Origin of Isolate }\end{array}$ & Isolat//solate & $\begin{array}{l}\text { Uji Katalase/ } \\
\text { Catalase Test }\end{array}$ & $\begin{array}{c}\text { Uji Oksidase/ } \\
\text { Oxidase Test }\end{array}$ & $\begin{array}{c}\text { Pewarnaan Gram/ } \\
\text { Gram Staining }\end{array}$ \\
\hline 1. & Bangka & RTB1. 1 & Positif (+) & Negatif (-) & Gram positif (+) \\
\hline 2. & Bangka & RTB1. 2 & Positif $(+)$ & Negatif (-) & Gram positif $(+)$ \\
\hline 3. & Bangka & RTB1. 3 & Positif $(+)$ & Negatif (-) & Gram positif $(+)$ \\
\hline 4. & Bangka & RTB2. 1 & Positif (+) & Negatif (-) & Gram positif $(+)$ \\
\hline 5. & Bangka & RTB2. 2 & Positif (+) & Negatif (-) & Gram positif $(+)$ \\
\hline 6. & Bangka & RTB2. 3 & Positif (+) & Negatif (-) & Gram positif $(+)$ \\
\hline 7. & Bangka & RAI. 1 & Negatif (-) & Negatif (-) & Gram positif $(+)$ \\
\hline 8. & Bangka & RAI. 2 & Negatif (-) & Negatif (-) & Gram positif $(+)$ \\
\hline 9. & Kalimantan & RK1. 1 & Negatif (-) & Negatif (-) & Gram positif $(+)$ \\
\hline 10. & Kalimantan & RK1. 2 & Negatif (-) & Negatif (-) & Gram positif $(+)$ \\
\hline 11. & Kalimantan & RK1. 3 & Negatif (-) & Negatif (-) & Gram positif $(+)$ \\
\hline 12. & Kalimantan & RK2. 1 & Negatif (-) & Negatif (-) & Gram positif $(+)$ \\
\hline 13. & Kalimantan & RK2. 2 & Negatif (-) & Negatif (-) & Gram positif $(+)$ \\
\hline 14. & Kalimantan & RK2. 3 & Negatif (-) & Negatif (-) & Gram positif $(+)$ \\
\hline 15. & Kalimantan & RK2. 4 & Negatif (-) & Negatif (-) & Gram positif $(+)$ \\
\hline 16. & Kalimantan & RK4. 1(RK4) & Negatif (-) & Negatif (-) & Gram positif $(+)$ \\
\hline 17. & Kalimantan & RK4. 2 & Negatif (-) & Negatif (-) & Gram positif $(+)$ \\
\hline 18. & Kalimantan & RK4. 3 & Negatif (-) & Negatif (-) & Gram positif (+) \\
\hline
\end{tabular}

aktivitas antimikroba bakteri asam laktat dapat dilihat pada Tabel 2.

Keempat isolat memperlihatkan spektrum penghambatan yang sempit, yaitu hanya mampu menghambat Staphylococcus aureus dari kelompok bakteri Gram positif. Hasil ini serupa dengan Mathieu et al. (1993) dan Hechard et al. (1992) dalam De Martins \& Freitas (2003) yang melaporkan bahwa bakteriosin yang dihasilkan oleh bakteri asam laktat tidak efektif dalam mengambat bakteri Gram negatif.
Hal ini kemungkinan berhubungan dengan adanya lapisan lipopolisakarida (LPS) dari dinding sel bakteri Gram negatif yang melindungi membran sel, sebagai lokasi target bakteriosin (Stevens et al., 1991 dalam De Martins \& Freitas, 2003). Selain itu daya hambat yang dihasilkan oleh keempat isolat kemungkinan juga disebabkan oleh adanya kompetisi nutrisi, asam laktat, diasetil, dan hidrogen peroksida (Klaenhammer, 1988 dalam Liu et al., 2008; Abrams et al., 2011). Berdasarkan hal tersebut, maka untuk pengujian

Tabel 2. Aktivitas antimikroba BAL

Table 2. Antimicrobe activity of $L A B$

\begin{tabular}{cccccccc}
\hline & \multirow{6}{*}{ Node/ } & \multicolumn{5}{c}{ Zona Hambat Isolat $(\mathrm{mm}) /$ Inhibition Zone of Isolate $(\mathbf{m m})$} \\
\cline { 3 - 7 } & Code & Vibrio sp. & S. aureus & L. monocytogenes & E. coli & Salmonella sp. & L. lactis \\
\hline 1. & RK1 & 0 & $2.0 \mathrm{~mm}$ & 0 & 0 & 0 & 0 \\
2. & RK2 & 0 & $5.0 \mathrm{~mm}$ & 0 & 0 & 0 & 0 \\
3. & RK4 & 0 & $5.0 \mathrm{~mm}$ & 0 & 0 & 0 & 0 \\
4. & RAI & 0 & $5.0 \mathrm{~mm}$ & 0 & 0 & 0 & 0 \\
\hline
\end{tabular}


selanjutnya hanya digunakan Staphylococcus aureus sebagai bakteri uji. Selanjutnya terhadap keempat isolat BAL yang memiliki aktivitas antimikroba dilakukan pengujian aktivitas supernatannya terhadap enzim proteolitik. Uji tersebut dilakukan untuk tujuan konfirmasi yang membuktikan bahwa supernatan yang dihasilkan oleh isolat BAL merupakan bakteriosin yang sesungguhnya.

\section{Konfirmasi BAL penghasil bakteriosin}

Bakteriosin adalah substrat dengan sifat alami protein sehingga sensitif terhadap aktivitas enzim proteolitik, diantaranya papain dan proteinase-K. Keempat isolat BAL yang memiliki aktivitas antimikroba selanjutnya dikonfirmasi kemampuannya sebagai penghasil bakteriosin melalui uji sensitifitas BAL tersebut terhadap aktivitas enzim proteolitik. Hasil uji sensitifitas bakteriosin terhadap enzim proteolitik dapat dilihat pada Tabel 3.

Aktivitas antibakteri dari supernatan RK2 masih ada setelah ditambahkan dengan enzim papain. Mekanisme penghambatan strain ini kemungkinan disebabkan oleh kompetisi substrat atau pengasaman media (Osmanagaoglu et al., 1998). Penambahan enzim proteinase- $K$ menyebabkan hilangnya aktivitas antimikroba pada RK1, RK2, dan RK4. Sementara RAI masih menunjukkan adanya aktivitas.

Supernatan yang dihasilkan oleh RK4 (Rusip Kalimantan) masih menunjukkan aktivitas sebelum diberi perlakuan enzim proteolitik, namun aktivitas supernatan menjadi hilang ketika diberi perlakuan enzim Proteinase-K dan papain. Papain merupakan enzim hidrolase sistein protease yang ada pada pepaya. Enzim proteinase-K dan papain keduanya merupakan enzim proteolitik (enzim pemecah protein). Karena pada dasarnya bakteriosin merupakan senyawa protein, maka keberadaan kedua enzim proteolitik tersebut di dalam sistem larutan enzim bakteriosin menyebabkan hilangnya aktivitas bakteriosin. Hal ini mengindikasikan bahwa senyawa antibakteri yang dihasilkan RK4 (Rusip Kalimantan) memiliki karakteristik yang sama seperti bakteriosin. Hasil uji sensitivitas keempat bakteri tersebut (RK1, RK2, RK4, dan RAI) terhadap aktivitas enzim proteolitik (Tabel 3) memperlihatkan bahwa RK4 memiliki karakteristik yang terbaik sebagai penghasil bakteriosin. Selanjutnya terhadap supernatan isolat RK4 dilakukan pengujian karakterisasi bakteriosin. Bakteriosin dinyatakan sebagai protein atau senyawa protein yang memiliki sifat antagonis terhadap bakteri (De Vuyst \& Vandamme, 1994). Sebagai senyawa antibakteri, bakteriosin bersifat sensitif terhadap enzim proteolitik, mengalami inaktivasi sempurna atau tereduksi secara signifikan setelah diberi perlakuan enzim proteinase-K, pronase dan tripsin (Todorov \& Dicks, 2005; Biscola et al., 2013). Proteinase-K dan pepsin sangat kuat menghambat produksi bakteriosin, sementara $\alpha$-amilase, DNase, RNase dan lipase tidak menghambat produksi bakteriosin (Rajaram et al., 2010).

\section{Karakterisasi bakteriosin}

\section{Pengaruh pH}

Produksi bakteriosin tergantung pada kondisi $\mathrm{pH}$, dengan kata lain $\mathrm{pH}$ sangat berperan dalam produksi bakteriosin (Lejeune et al. dalam De Vyust \& Leroy, 2007; Delgado et al. dalam Altuntas et al., 2010). Hasil uji sensitifitas bakteriosin terhadap pH disajikan pada Gambar 1.

Hasil penelitian ini sedikit berbeda dengan bakteriosin yang dihasilkan oleh Lactobacillus sakei R1333 yang masih stabil aktivitasnya setelah diinkubasi pada $\mathrm{pH} 2,0 ; 4,0 ; 6,0 ; 8,0 ; 10,0$; dan 12,0, namun hasilnya serupa dengan bakteriosin yang dihasilkan oleh L. brevis OG1 yang masih stabil pada pH 2-8 (Ogunbanwo et al., 2003; Todorov et al., 2011a). Pada penelitian ini, hilangnya aktivitas

Tabel 3. Pengaruh enzim proteolitik terhadap aktivitas bakteriosin

Table 3. Effect of proteolytic enzyme on bacteriocin activity

\begin{tabular}{|c|c|c|c|c|c|}
\hline \multirow{2}{*}{$\begin{array}{l}\text { Perlakuan Enzim/ } \\
\text { Enzyme Treatments }\end{array}$} & \multirow{2}{*}{$\begin{array}{l}\text { Konsentrasi }(\mathrm{mg} / \mathrm{ml}) / \\
\text { Concentration }(\mathrm{mg} / \mathrm{ml})\end{array}$} & \multicolumn{4}{|c|}{ Aktivitas Bakteriosin/Bacteriocin Activit] } \\
\hline & & RK1 & RK2 & RK4 & RAI \\
\hline Kontrol & - & + & + & + & + \\
\hline Papain & 0.1 & - & + & - & - \\
\hline Proteinase- $\mathrm{K}$ & 0.1 & - & - & - & + \\
\hline
\end{tabular}

Keterangan/Note: Kontrol adalah larutan bakteriosin tanpa diberi perlakuan enzim/

Control was bacteriocin solution without enzyme treatment 


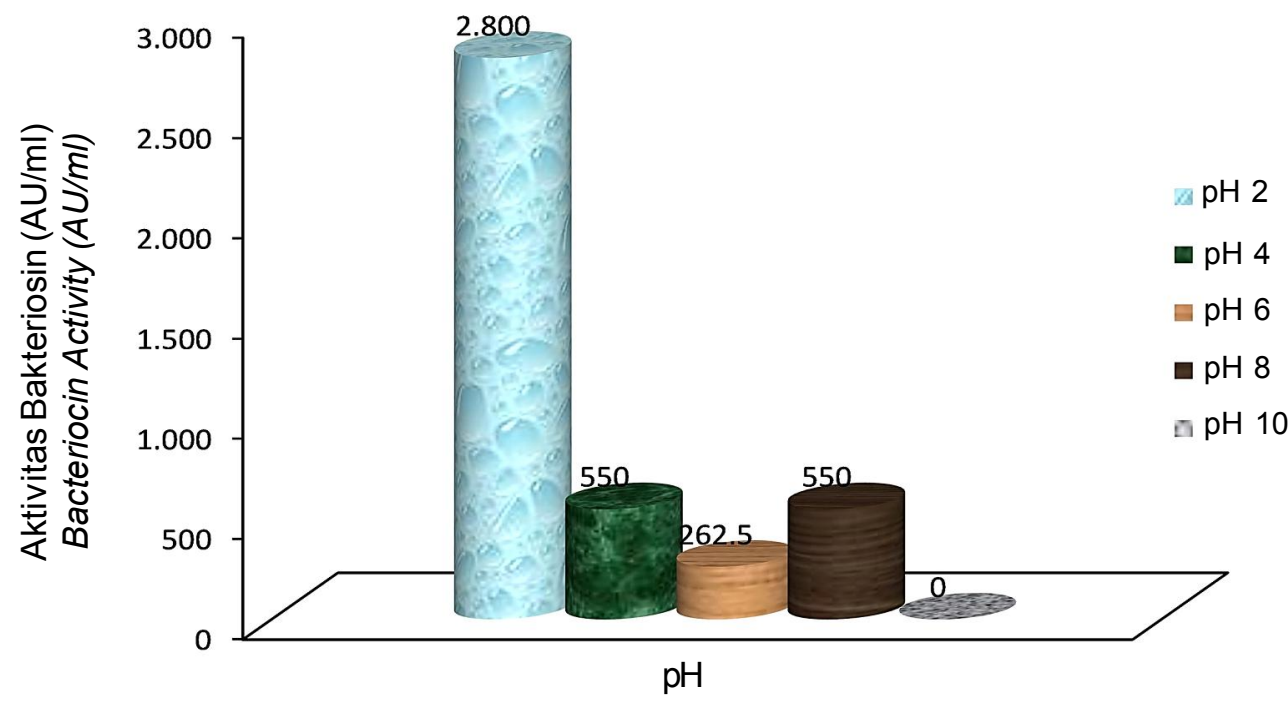

Gambar 1. Pengaruh pH terhadap aktivitas bakteriosin.

Figure 1. Effect of $\mathrm{pH}$ on bacteriocin activity.

bakteriosin pada $\mathrm{pH} 10$ kemungkinan disebabkan terdegradasi oleh enzim proteolitik, agregasi protein, diserap oleh sel penghasil dan regulasi umpan balik (Parente et al., 1994 dalam Todorov \& Dicks, 2006). Degradasi bakteriosin terjadi seiring dengan fase kematian sel penghasil. Awalnya sel mengalami lisis kemudian diikuti dengan akumulasi protease intraseluler yang menyebabkan rusaknya bakteriosin (Avonts et al., 2004).

\section{Stabilitas terhadap panas}

Bakteriosin RK4 (Rusip Kalimantan) memiliki stabilitas panas yang kuat bahkan setelah disterilisasi pada suhu $121^{\circ} \mathrm{C}$ selama 15 menit. Berdasarkan karakter ini maka bakteriosin tersebut dapat digunakan sebagai pengawet makanan yang diolah dengan suhu tinggi, di samping berperan penting untuk aplikasi pengolahan dan konservasi pangan (Gao et al., 2010). Hasil serupa telah dilaporkan pada bakteriosin yang dihasilkan oleh L. plantarum F1 dan L. brevis OG1 yang masih menunjukkan aktivitas pada pemanasan suhu $100{ }^{\circ} \mathrm{C}$ selama $10-30$ menit dan pemanasan pada suhu $121^{\circ} \mathrm{C}$ selama $10-60$ menit. Penelitian lain menyebutkan bahwa bakteriosin ST16Pa masih stabil setelah dipanaskan pada suhu $25-100{ }^{\circ} \mathrm{C}$ selama 2 jam dan tidak terjadi pengurangan aktivitas setelah diberi perlakuan suhu $121^{\circ} \mathrm{C}$ selama 20 menit pada pH 6,0 (Ogunbanwo et al., 2003; Todorov \& Dicks, 2006; Todorov et al., 2011b).

Bakteriosin yang dihasilkan oleh RK4 masih menunjukkan aktivitas ketika diberi perlakuan panas pada suhu 50,100 , dan $121^{\circ} \mathrm{C}$ (Tabel 4) sehingga sementara diduga bahwa senyawa antibakteri yang dihasilkan oleh RK4 (Rusip Kalimantan) adalah bakteriosin. Masih adanya aktivitas antibakteri oleh bakteriosin ketika diberi perlakuan panas diduga karena bakteriosin merupakan peptida pendek yang stabil terhadap panas. Selain itu karena adanya asam amino tertentu pada bakteriosin tersebut yang mampu mempertahankan struktur bakteriosin dari pengaruh panas (Ray, 1992; Rahayu et al., 2004).

\section{Pengaruh surfaktan}

Penambahan surfaktan dapat mempengaruhi aktivitas bakteriosin. Dalam hal ini, surfaktan EDTA, SDS, dan laurylsarcosine dapat meningkatkan aktivitas bakteriosin. Dilaporkan telah terjadi laju adsorpsi bakteriosin yang tinggi dengan keberadaan senyawa kimiawi seperti $\mathrm{NaCl}$, gliserol dan SDS. Adsorpsi bakteriosin terhadap sel target sangat penting karena sebagai perantara terjadinya insersi bakteriosin ke dalam membran sel dan dalam membentuk pori yang menjadi sebab terjadinya kematian sel (Todorov, 2009 dalam Biscola et al., 2013). Sebaliknya, bioaktivitas bakteriosin RK4 tidak dipengaruhi oleh triton $\mathrm{x}-100$, tween 20 , tween 80 , dan urea. Pengaruh surfaktan terhadap aktivitas bakteriosin disajikan pada Gambar 2. EDTA diketahui memiliki aktivitas antimikroba terutama terhadap bakteri Gram negatif. Dalam hal ini, EDTA dapat mengganggu struktur membran luar dan memberi akses bagi molekul hidrofobik masuk ke dalam membran sitoplasma (Vaara, 1992 dalam Kusmarwati et al., 2012). Sementara itu, surfaktan non ionik triton $\mathrm{x}$ - 100, tween 80 dan tween 20 tidak berpengaruh terhadap aktivitas bakteriosin (meskipun penelitian lain melaporkan bahwa penambahkan deterjen non ionik untuk berbagai makanan dapat menginduksi produksi bakteriosin). 
Tabel 4. Pengaruh suhu terhadap aktivitas bakteriosin Table 4. Effect of temperature on bacteriocin activity

\begin{tabular}{lc}
\hline \multicolumn{1}{c}{ Perlakuan/Treatment } & Aktivitas Bakteriosin/Bacteriocin Activity \\
\hline Kontrol/Control & + \\
$50{ }^{\circ} \mathrm{C}$ selama 20 menit $/ 50^{\circ} \mathrm{C}$ for 20 minutes & + \\
$100^{\circ} \mathrm{C}$ selama 20 menit $/ 100^{\circ} \mathrm{C}$ for 20 minutes & + \\
$121^{\circ} \mathrm{C}$ selama 15 menit $/ 21^{\circ} \mathrm{C}$ for 15 minutes & + \\
\hline
\end{tabular}

Keterangan/Note: Kontrol adalah larutan bakteriosin tanpa diberi perlakuan/ Control was bacteriocin solution without treatment

Tween diperlakukan juga untuk meningkatkan aktivitas supernatan. Namun, efeknya bergantung jenis bakterinya (Reese \& Maguire, 1969 dalam Castro, 2011). Peningkatan ini mungkin disebabkan karena pengaruh surfaktan terhadap permeabilitas membran sel (Ogunbanwo et al. 2003).

\section{Stabilitas bakteriosin selama penyimpanan}

Uji stabilitas bakteriosin dilakukan melalui penyimpanan bakteriosin pada suhu $-20,4$, dan 37 ${ }^{\circ} \mathrm{C}$ selama 4 minggu (Tabel 5). Bakteriosin yang dihasilkan oleh RK4 bersifat lebih stabil setelah penyimpanan selama 4 minggu pada suhu $37^{\circ} \mathrm{C}$ dan $4{ }^{\circ} \mathrm{C}$, namun tidak terdeteksi setelah penyimpanan pada suhu $-20^{\circ} \mathrm{C}$. Hal ini mengindikasikan bahwa penyimpanan bakteriosin tersebut hingga suhu $4^{\circ} \mathrm{C}$ mungkin merupakan teknik preservatif yang sesuai. Aktivitas serupa ditunjukkan oleh pentocin 31-1 yang dihasilkan oleh produk daging asal china Xuan-Wei
Ham (Liu et al., 2008). Selain itu berdasarkan aktivitas anti Stahylococcus yang ditunjukkan oleh bakteriosin RK4 dan sifatnya yang relatif lebih stabil pada suhu ruang dan suhu dingin, menunjukkan bahwa bakteriosin tersebut potensial digunakan sebagai pengawet pangan, khususnya pada produk pangan yang rentan terkontaminasi oleh bakteri Staphylococcus aureus.

Oleh karena itu, masih diperlukan riset yang berkaitan dengan aplikasi bakteriosin tersebut pada produk pangan terutama yang disimpan pada suhu ruang dan suhu dingin.

\section{Identifikasi isolat RK4}

Metode untuk mengidentifikasi mikroorganisme manual ke tingkat spesies dapat menggunakan produk identifikasi bioMérieux API yaitu test kit untuk identifikasi bakteri Gram positif, Gram negatif, dan ragi.

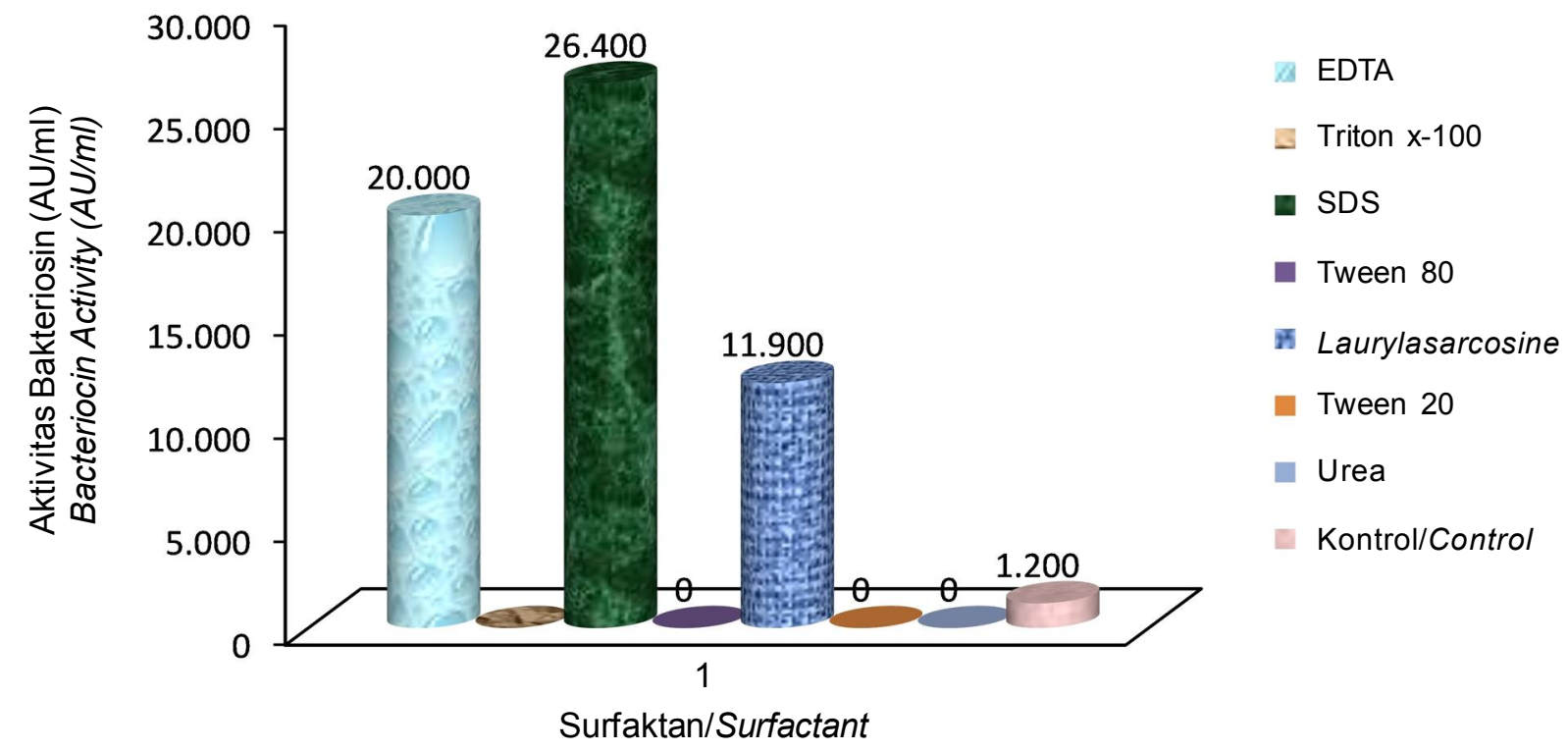

Gambar 2. Pengaruh surfaktan terhadap aktivitas bakteriosin.

Figure 2. Effect of surfactant on bacteriocin activity. 
Tabel 5. Stabilitas bakteriosin

Table 5. Stability of bacteriocin

\begin{tabular}{ccccc}
\hline \multirow{2}{*}{$\begin{array}{c}\text { Suhu Penyimpanan/ } \\
\text { Storage Temperature }\end{array}$} & \multicolumn{4}{c}{ Aktivitas Bakteriosin/Bacteriocin Activity } \\
\cline { 2 - 5 } & Minggu ke-1/ & Minggu ke-2/ & Minggu ke-3/ & Minggu ke-4/ \\
1st week & 2nd week & 3rd week & 4th week \\
\hline $37^{\circ} \mathrm{C}$ & + & + & + & + \\
$4{ }^{\circ} \mathrm{C}$ & + & + & - & - \\
$-20{ }^{\circ} \mathrm{C}$ & - & - & - & - \\
\hline
\end{tabular}

Berdasarkan karakteristik fisiologis dan biokimia dengan menggunakan test kit API $50 \mathrm{CH}$ dan API 50 CHL medium versi 5.1 (biomerieoux) yang dilanjutkan dengan pengolahan dan analisis menggunakan software APIWEB, maka strain bakteriosin yang diisolasi dari isolat BAL tersebut teridentifikasi sebagai Pediococcus pentosaceus 1 dengan kategori indikasi baik $(99,7 \%)$. Strain RK4 merupakan Gram positif, berbentuk coccus, katalase negatif dan oksidase negatif. Strain RK4 mampu memfermentasi gula seperti ribosa, galaktosa, glukosa, fruktosa, manosa, selobiosa, maltosa, laktosa, sakarosa, trehalosa dan gentobiose. Karakteristik fisiologi dan biokimia isolat RK4 dapat dilihat pada Tabel 6.
Hasil tes kitAPI $50 \mathrm{CHL}$ dapat dilihat pada Gambar 3. Hasil positif (+) ditandai dengan perubahan warna dari biru menjadi kuning setelah diinkubasi selama 48 jam, sedangkan yang memiliki hasil negatif (-) tidak mengalami perubahan warna (tetap berwarna biru).

\section{KESIMPULAN DAN SARAN}

Dari sampel rusip yang berasal dari Bangka dan Kalimantan telah diperoleh 12 isolat BAL. Selanjutnya dari kedua belas isolat BAL tersebut diperoleh 1 isolat BAL (RK4) asal Kalimantan yang mampu menghasilkan bakteriosin. Isolat RK4 yang teridentifikasi sebagai Pediococcus pentosaceus I

Tabel 6. Karakteristik fisiologis dan biokimia isolat RK4

Table 6. Physiological and biochemical characteristics of isolate RK4

\begin{tabular}{ll}
\hline \multicolumn{1}{c}{$\begin{array}{c}\text { Karakteristik Fisiologi dan Biokimia/ } \\
\text { Physiological and Biochemical Characteristics }\end{array}$} & \multicolumn{1}{c}{ Hasil/Results } \\
\hline Morfologi koloni/Colony morphology & Putih,koloni bulat halus/ \\
& White, smooth round colonies \\
Pewarnaan Gram/Gram staining & Gram positif, coccus/Gram positive, coccus \\
Pertumbuhan di MRS broth/Growth in MRS broth & Keruh/Turbid \\
& L-Arabinosa, Ribosa, Galaktosa, D-Glukosa, D- \\
Fermentasi positif/ & Fruktosa, D-Mannosa, N-Asetilglukosamin, \\
Fermentation positive to & Amigdalin, Arbutin, Salisin, Selobiosa, Maltosa, \\
& Trehalosa, D-Tagatosa/ L-Arabinose, Ribose, \\
& Galactose, D-Glucose, D-Fructose, D-Mannose, \\
& N-Acetylglucosamine, Amygdalin, Arbutin, \\
& Salicin, Cellobiose, Maltose, Trehalose, D- \\
& Tagatose \\
Uji katalase/Catalase test & Negatif/Negative \\
Uji oksidase/Oxidase test & Negatif/Negative \\
Identifikasi/Identification & Pediococcus pentosaceus 1 \\
\% ID & 99.7\% \\
\hline
\end{tabular}




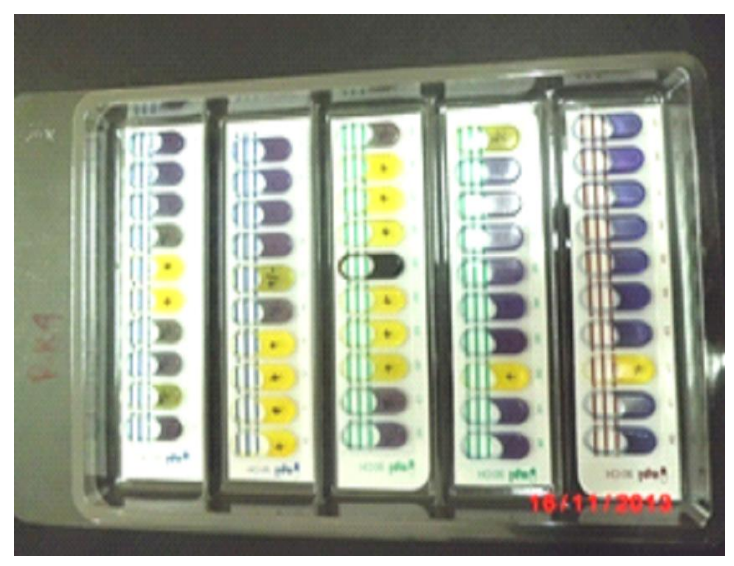

Gambar 3. Hasil identifikasi isolat RK4 setelah 48 jam pasca inokulasi pada Tes Kit API 50 CHL. Reaksi positif ditunjukkan warna kuning.

Figure 3. Identification result of isolat RK4 after inoculation for $48 \mathrm{~h}$ using API $50 \mathrm{CHL}$. Positive reaction was shown by yellow colour.

menghasilkan bakteriosin yang bersifat sensitif terhadap enzim proteolitik proteinase-K dan papain. Bakteriosin yang dihasilkan bersifat stabil hingga mencapai suhu $121^{\circ} \mathrm{C}$, stabil pada $\mathrm{pH} 2-8$, memiliki spektrum penghambatan sempit hanya terhadap Staphylococcus aureus dan aktivitasnya distimulasi oleh surfaktan SDS, laurylsarcosine dan EDTA. Sebaliknya Tween 20, Tween 80, Triton X-100 dan urea justru menghambat aktivitasnya. Bakteriosin kasar RK4 stabil pada penyimpanan suhu $37^{\circ} \mathrm{C}$ selama 4 minggu dan pada suhu dingin selama 2 minggu.

\section{DAFTAR PUSTAKA}

Abrams, D., Barbosa, J., Albano, H., Silva, J., Gibbs, P., \& Teixeira, P. (2011). Characterization of bacPPK34 a bacteriocin produced by Pediococcus pentosaceus strain K34 isolated from "Alheira". Food Control. 22: 940-946.

Alegría, A., Delgado, S., Roces, C., López, B., \& Mayo, B. (2010). Bacteriocins produced by wild Lactococcus lactis strains isolated from traditional, starter-free cheeses made of raw milk. International Jounal of Food Microbiology. 143(1-2): 6-61.

Altuntas, E.G., Cosansu, S., \& Ayhan, K. (2010). Some growth parameters and antimicrobial activity of a bacteriocin-producing strain Pediococcus acidilactici 13. International Journal of Food Microbiology. 141: 28-31.

Avonts, L., Van Uytven, E., \& De Vuyst, L. 2004. Cell growth and bacteriocin production of probiotic Lactobacillus strains in different media. International Dairy Journal 14: 947-955.

Axelsson, L. (2004). Lactic acid bacteria : Classification and Physiology. In Salminen, S., Wright, A.V., and Ouwehand. (eds). Lactic Acid Bacteria. Microbiological and Fungtional Aspects Third Edition. Revised and Expanded : 1-66.
Biscola, V., Todorov, S.D., Capuano, V.S.C., Abriouel, H., Galvez, A., \& Franco, B.D.G.M. (2013). Isolation and characterization of a nisin-like bacteriocin produced by a Lactococcus lactis strain isolated from charqui, a Brazilian fermented, salted and dried meat product. Meat Science. 93: 607-613.

Barbosa, M.S., Todorov, S.D., \& Jurkiewicz, C.H. (2015). Bacteriocin production by Lactobacillus curvatus MBSa2 entrapped in calcium alginate during ripening of salami for control of Listeria monocytogenes. Food Control. 47: 147-153.

Con, A.H. \& GoÈ kalp, H.Y. (2000). Production of bacteriocin-like metabolites by lactic acid cultures isolated from sucuk samples. Meat Science. 55: 8996.

Castro, M.P., Palavecino, N.Z., Herman, C., Garro, O.A., \& Campos, C.A. (2011). Lactic acid bacteria isolated from artisanal dry sausages: Characterization of antibacterial compounds and study of the factors affecting bacteriocin production. Meat Science. 87: 321-329.

Cladera-Olivera, F., Caron, G.R., \& Brandelli, A. (2004). Bacteriocin production by Bacillus licheniformis strain P40 in cheese whey using response surface methodology. Biochemical Engineering Journal. 21 (1): 53-58.

De Arauz, L.J., Jozala, A.F., Mazolla, P.G., \& Penna, T.C.V. (2009). Nisin biotechnological production and application: a review. Trend in Food Science \& Technology. 20: 146-154.

De Martinis, E.C.P., \& Freitas, F.Z. (2003). Screening of lactic acid bacteria from Brazilian meats for bacteriocin formation. Food Control. 14(3): 197-200.

De Vuyst, L. \& Vandamme, E.J. (1994). Bacteriocins of Lactic Acid Bacteria: Microbiology, Genetics and Applications. Blackie Academic and Professional, London.

De Vyust, L. \& Leroy, F. (2007). Bacteriocins from lactic acid bacteria : production, purification, and food 
applications. J. Mol Microbiol Biotechnol. 13: 194199.

Delgado, A., Francisco No'e Arroyo L'opez, F. N.A., Brito, D., Peres, C., Fevereiro, P., \& Garrido-Fern'andez, A. (2007). Optimum bacteriocin production by Lactobacillus plantarum $17.2 \mathrm{~b}$ requires absence of $\mathrm{NaCl}$ and apparently follows a mixed metabolite kinetics. Journal of Biotechnology.130: 193-201.

Galvez, A., Abriouel, H., Lopez, R.L. \& Omar, N.B. (2007). Bacteriocin-based strategies for food preservation. International Journal of Food Microbiology. 120: 5170.

Gao, Y., Jia, S., Gao, Q., \& Zhilei. (2010). A novel bacteriocin with broad inhibitory spectrum produced by Lactobacillus sake C2, isolated from traditional Chinese fermented cabbage. Food Control. 21: 7681.

Hata, T., Tanaka, R., \& Ohmomo, A. (2010). Isolation and characterization of plantaricin ASM1: A new bacteriocin produced by Lactobacillus plantarum A-1. International Journal of Food Microbiology. 137: 9499.

Hurtado, A., Reguant, C., Bordons, A., \& Rozès, N. (2011). Expression of Lactobacillus pentosus B96 bacteriocin genes under saline stress. Food Microbiology. 28(8): 1514-8.

Kaewkloma, S., Lumlert, S., Kraikul, W., \& Aunpada, R. (2013). Control of Listeria monocytogenes on sliced bologna sausage using a novel bacteriocin, amysin, produced by Bacillus amyloliquefaciens isolated from Thai shrimp paste (Kapi). Food Control. 32: 552557.

Klaenhammer, T.R. (1988). Bacteriocins of lactic acid bacteria. Biochimie. 70: 337-349.

Kusmarwati A. \& Indriati, N. (2012). Karakteristik bakteri asam laktat asal rusip sebagai agen probiotik. Jurnal Pasca Panen dan Bioteknologi Kelautan dan Perikanan. 7(2): 159-170.

Kusmiati \& Malik, A. (2002). Bacteriocin activity of Leuconostoc mesenteroides Pbac1 bacteria on several media. Makara, Health. 6(1): 1-7.

Liu, G., Lv, Y., Li, P., Zhou, K. \& Zhang, J. (2008). Pentocin 31-1, an anti-Listeria bacteriocin produced by Lactobacillus pentosus 31-1 isolated from Xuan-Wei Ham, a traditional China fermented meat product. Food Control. 19: 353-359.

Mandal, V., Sen, S.K. \& Mandal, N.C. (2008). Optimized cultured conditions for bacteriocin production by Pediococcus acidilactici $\mathrm{LAB}$ and its characterization. Indian Journal of Biochemistry \& Biophysics. 45: 106110.

Nugroho, D.A. \& Rahayu, E.S. (2003). Extraction and characterization of bacteriocin produced by Leuconostoc mesenteroides SM 22. J. Technol and Food Industry. 14(3).

Omar, N. B., Abriouel, H., Lucas, R., Martinez-Canamero, M., Guyot, J. \& Galvez, A. (2006). Isolation of bacteriocinogenic Lactobacillus plantarum strains from ben saalga, a traditional fermented gruel from
Burkina Faso. International Journal of Food Microbiology. 112: 44-50.

Ogunbanwo, S.T., Sanni, A.I. \& Onilude, A.A. (2003). Characterization of bacteriocin produced by Lactobacillus plantarum F1 and Lactobacillus brevis OG1. African Journal of Biotechnology. 2(8): 219-227.

Osmanagaoglu, O., Gunduz, U., Beyatli, Y., \& Cokmus, C. (1998). Purification and characterization of Pediocin F.A bacteriocin produced by Pediococcus acidilactici F. Tr. J. of Biology. 22: 217-228.

Rahayu, E.S. \& Margino, S. (1997). Bakteri Asam Laktat: Isolasi dan Identifikasi. Materi Workshop, PAU Pangan dan Gizi Universitas Gadjah Mada.

Rahayu, E.S., Ekasari, A., Wardhani, A.K., \& Margino, S. (1999). Screening of Lactic Acid Bacteria from Meat and Meat Product as Bacteriocin Producer. Proceeding of Food National Conference, Yogyakarta.

Rahayu, E.S., Wardani, A.K., \& Margino, S. (2004). Skrining bakteri asam laktat penghasil bakteriosin dari daging dan produk olahannya. Agritech. 24(2): 74-81.

Rajaram, G., Manivasagan, P., Thilagavathi, B., \& Saravanakumar, A. (2010). Purification and characterization of a bacteriocin produced by Lactobacillus lactis isolated from marine environment. Advance Journal of Food Science and Technology. 2(2): 138-144.

Ray, B. (1992). Fundamental Food Microbiology. CRC Press. London. $516 \mathrm{p}$.

Sakti, T.P.J. (2009). Analysis Probiotic of Lactic Acid Bacteria from Rusip. Schript. Departement of Agriculture Sriwijaya University. $35 \mathrm{pp}$.

Syahniar, T.M. (2009). Production and Characterization of Bacteriosin from Lactobacillus plantarum 1A5 and Antimicrobial Activity to Pathogen Bacteria. Schript. IPB Bogor. $61 \mathrm{pp}$.

Todorov, S.D. \& Dicks. (2005). Effect of growth medium on bacteriocin production by Lactobacillus plantarum ST194BZ, a strain isolated from Boza. Food Technol Biotechnol. 43: 165-173.

Todorov, S.D. \& Dicks, L.M.T. (2006). Screening for bacteriocin-producing lactic acid bacteria from boza, a traditional cereal beverage from Bulgaria Comparison of the bacteriocins. Process Biochemistry. 41: 11-19.

Todorov, S.D., Prevost, H., Lebois, M., Dousset, X., LeBlanc, J.G., \& Franco, B.DGM. (2011a). Bacteriocinogenic Lactobacillus plantarum ST16Pa isolated from papaya (Carica papaya)-from isolation to application: Characterization of a bacteriocin. Food Research International. 44: 1351-1363.

Todorov, SD., Rachman, C., Fourrier, A., Dicks, Leon MT., Van Reenen., Pre'vost, H., \& Dousset, X. (2011b). Characterization of a bacteriocin produced by Lactobacillus sakei R1333 isolated from smoked salmon. Anaerobe. 17: 23-31.

Udhayashree, N., Senbagam, D., \& Senthilkumar, B. (2012). Production of bacteriocin and their application in food products. Asian Pacific Journal of Tropical Biomedicine. S406-S410. 
Usmiati, S. \& Marwati, T. (2007). Selection and optimation of process of bacteriocin production from Lactobacillus sp. J. Post Harvest. 4(1): $27-37$.
Yuliana, N. (2007). Profile of rusip fermentation made from anchovies (Stolephorus sp). Agritech. 27(1): 1217. 